\title{
PERAN NOTARIS TERKAIT PENGESAHAN PERJANJIAN PERKAWINAN PASCA PUTUSAN MAHKAMAH KONSTITUSI NOMOR 69/PUU-XIII/2015
}

Fhauzi Prasetyawan

Fakultas Hukum Universitas Brawijaya

Jl. Veteran Malang, Magister Kenotariatan, Telp, (0341) 551611. Telp2, (0341) 575777. Fax, (0341) 565420. Kodepos 65145, e-mail: fhauzi6389@gmail.com

\begin{abstract}
Abstrak
Pengesahan perjanjian perkawinan merupakan unsur penting di dalam perjanjian perkawinan, karena pengesahan tersebut menentukan keterikatan pihak ketiga kedalam suatu perjanjian perkawinan. Perjanjian perkawinan disahkan oleh Pegawai Pencatatan Perkawinan dimana perkawinan tersebut dicatatkan. Pasca Putusan MK No. 69/PUUXIII/2015 pengesahan perjanjian perkawinan tidak hanya menjadi kewenangan dari pegawai pencatatan perkawinan melainkan juga menjadi kewenangan dari Notaris. Tujuan penelitian ini adalah untuk mengetahui apa saja peran Notaris terkait pengesahan perjanjian perkawinan pasca putusan MK tersebut. Penelitian ini tergolong penelitian yuridis normatif yang menggunakan pendekatan undang-undang dan konseptual. Hasil penelitian menunjukan bahwa ada 2 (dua) peran Notaris terkait pengesahan perjanjian perkawinan pasca Putusan MK No. 69/PUU-XIII/2015, yaitu Notaris sebagai pihak yang berwenang mengesahkan perjanjian perkawinan sebagai perjanjian tertulis dalam artian membuat perjanjian perkawinan ke dalam akta Notaris dan Notaris sebagai pihak yang berwenang untuk mengesahkan perjanjian perkawinan dengan tujuan agar perjanjian perkawinan itu mengikat juga bagi pihak ketiga.
\end{abstract}

Kata kunci: Pengesahan, Perjanjian perkawinan, Notaris, Putusan Mahkamah Konstitusi

\section{A.Pendahuluan}

Salah satu hal yang tidak dapat dipisahkan dari perkawinan adalah harta benda. Wahyono Darmabrata berpendapat "Seorang pria dengan seorang wanita setelah melakukan perkawinan akan menimbulkan akibat-akibat hukum yaitu antara lain mengenai hubungan hukum antara suami istri dan mengenai harta benda serta penghasilan mereka". ${ }^{1}$

\footnotetext{
${ }^{1}$ Wahyono Darmabrata, (2009), Hukum Perkawinan Perdata (Syarat Sahnya Perkawinan, Hak dan Kewajiban Suami Istri, Harta Benda Perkawinan), Jakarta: Rizkita, hlm. 128.
}

Harta benda dalam perkawinan adalah salah satu modal demi keberlangsungan kehidupan sebuah keluarga, selain itu harta benda dalam perkawinan juga berfungsi sebagai jaminan bagi pihak ketiga yang terlibat dengan perikatan yang dibuat oleh pasangan suami istri. ${ }^{2}$ Memandang harta

\footnotetext{
${ }^{2}$ Moch. Isnaaeni, Problematika Perjanjian Kawin Pasca Putusan Mahkamah Konstitusi No. 69/PUUXIII/2015, Makalah disajikan dalam Seminar Nasional, Himpunan Mahasiswa Kenotariatan Universitas Airlangga, Surabaya, 5 Desember 2016, hlm. 12.
} 
benda erat kaitannya dengan perkawinan, maka Undang-Undang Nomor 1 Tahun 1974 Tentang Perkawinan yang selanjutnya disebut "UU 1/1974" mengaturnya dalam beberapa pasal. Adapun pasal yang mengatur harta benda dalam perkawinan adalah sebagai berikut:

a. Pasal 35

(1) Harta benda yang didapat selama masa perkawinan menjadi harta bersama.

(2) Harta bawaan dari masingmasing suami dan istri dan harta benda yang diperoleh masing-masing sebagai hadiah atau warisan, adalah di bawah pengusaaan masing-masing sepanjang para pihak tidak menentukan lain.

b. Pasal 36

(1) Mengenai harta bersama suami atau istri dapat bertindak atas perjanjian kedua belah pihak.

(2) Mengenai harta bawaan masing-masing, suami dan istri mempunyai hak sepenuhnya untuk melakukan perbuatan hukum mengenai harta bendanya.

c. Pasal 37

Bila perkawinan putus karena perceraian, harta bersama diatur menurut hukum masing-masing. Dilihat dari uraian pasal-pasal yang mengatur tentang harta benda dalam perkawinan pada UU 1/1974 di atas, maka dapat disimpulkan bahwa UU 1/1974 mengenal adanya pembedaan harta benda dalam perkawinan menjadi harta bawaan dan harta bersama.

Harta bawaan adalah harta benda yang diperoleh suami atau istri sebelum masa perkawinan, termasuk yang diperoleh dari hadiah atau warisan. Mengenai tindakan penguasaan dan kepengurusan atas harta bawaan tersebut adalah hak masing-masing suami atau istri. $^{3}$

Harta bersama adalah harta benda yang yang diperoleh selama masa perkawinan. Mengenai tindakan penguasaan dan pengurusan atas harta bersama tersebut adalah hak bersama dari suami dan istri, sehingga apabila suami atau istri tersebut melakukan perbuatan hukum atas harta bersama tersebut maka diperlukan persetujuan dari suami atau istrinya. ${ }^{4}$

Peraturan dalam UU 1/1974 yang mengatur tentang harta benda dalam perkawinan terutama terkait dengan harta bersama, dapat disimpangi dengan adanya suatu kesepakatan bersama antara calon suami dan calon istri. Pasal 36 ayat (1) UU 1/1974 memperbolehkan adanya

${ }^{3}$ Khomariah, (2004), Hukum Perdata, Malang: UMM Press, hlm. 53-54.

${ }^{4}$ Khomariah, Loc. Cit.

Volume 2 No.1 April 2018

ISSN Cetak: 2579-9983, E-ISSN: 2579-6380

Halaman. 87-104 
penyimpangan terhadap peraturanperaturan yang terkait dengan harta bersama dalam perkawinan selama isi kesepakatan tersebut tidak melanggar hukum, agama dan kesusilaan.

Kesepakatan atas penyimpangan tersebut dituangkan kedalam suatu bentuk perjanjian tertulis yang disebut dengan dengan perjanjian perkawinan. Perjanjian perkawinan adalah cara untuk menyimpangi peraturan yang mengatur tentang harta benda dalam perkawinan, pada saat atau sebelum perkawinan berlangsung, calon suami dan calon istri berdasarkan kesepakatan bersama dapat membuat perjanjian secara tertulis yang selanjutnya disahkan oleh Pegawai Pencatat Perkawinan, yang isinya berlaku juga bagi pihak ketiga. ${ }^{5}$

Perjanjian perkawinan yang isinya mengenai pengaturan harta benda dalam perkawinan dibuat sepanjang tidak melanggar asas atau pola yang ditetapkan peraturan Undang-Undang. 6 Dalam UU 1/1974, perjanjian perkawinan diatur di dalam Bab $\mathrm{V}$ yang hanya terdiri dari 1 (satu) pasal, yaitu Pasal 29. Adapun

\footnotetext{
${ }^{5}$ Wahyono Darmabrata, (2008), Tinjauan UndangUndang No. 1 Tahun 1974 Tentang Perkawinan beserta Undang-Undang dan Peraturan Pelaksanaannya, Jakarta: Rizkita, hlm. 22.

${ }^{6}$ Subekti, (2004), Ringkasan Tentang Hukum Keluarga dan Hukum Waris, Cet. 4, Jakarta: PT. Intermasa, hlm. 8-9.
}

ketentuan dari pasal tersebut adalah sebagi berikut:

(1) Pada waktu atau sebelum perkawinan dilangsungkan, kedua pihak atas persetujuan bersama dapat mengadakan perjanjian tertulis yang disahkan oleh Pegawai Pencatat Perkawinan, setelah mana isinya berlaku juga terhadap pihak ketiga sepanjang pihak ketiga tersangkut.

(2) Perjanjian tersebut tidak dapat disahkan bilamana melanggar batas hukum, agama dan kesusilaan.

(3) Perjanjian tersebut berlangsung semenjak perkawinan dilangsungkan.

(4) Selama perkawinan berlangsung perjanjian tersebut tidak dapat diubah, kecuali bilamana dari kedua belah pihak ada persetujuan untuk mengubah dan perubahan tidak merugikan pihak ketiga.

Pada tanggal 27 Oktober 2016, Mahkamah Konstitusi menerbitkan Putusan Nomor 69/PUU-XIII/2015. Inti pokok dari putusan tersebut adalah seputar pengaturan mengenai perjanjian perkawinan yang ada di dalam Pasal 29 UU 1/1974. Putusan tersebut dinilai telah mengubah dan menambah norma dari suatu perjanjian perkawinan yang diatur oleh Pasal 29 UU 1/1974. Adapun 
beberapa perubahannya adalah sebagai berikut: $^{7}$

1. Sebelum Putusan Mahkamah Konstitusi perjanjian perkawinan hanya dapat dibuat sebelum atau pada saat perkawinan dilangsungkan, sesudah Putusan Mahkamah Konstitusi perjanjian perkawinan dapat dibuat sebelum, pada saat perkawinan dilangsungkan atau dalam masa ikatan perkawinan.

2. Sebelum Putusan Mahkamah Konstitusi pengesahan perjanjian perkawinan dilakukan oleh pegawai pencatatan perkawinan, Sesudah Putusan Mahkmah Konstitusi pengesahan perjanjian perkawinan dilakukan oleh pegawai pencatatan perkawinan atau Notaris.

3. Sebelum Putusan Mahkamah Konstitusi perjanjian perkawinan mulai berlaku pada saat setelah dilangsungkannya perkawinan, sesudah Putusan Mahkamah Konstitusi perjanjian perkawinan mulai berlaku pada saat setelah dilangsungkannya perkawinan, atau sepanjang ditentukan lain dalam perjanjian perkawinan.

4. Sebelum Putusan Mahkamah Konstitusi perjanjian perkawinan hanya dapat

\footnotetext{
${ }^{7}$ Arko Kanadianto, (2016), Pembuatan Perjanjian Pisah Harta Pasca Putusan Mahkamah Konstitusi No. 69/PUU-XIII/2015 (online), http://arkokanadianto.com/, (10 Maret 2017).
}

diubah dengan persetujuan kedua belah pihak sepanjang perubahan itu tidak merugikan pihak ketiga, sesudah Putusan Mahkamah Konstitusi perjanjian perkawinan bisa diubah atau dicabut dengan persetujuan kedua belah pihak sepanjang perubahan dan pencabutan itu tidak merugikan pihak ketiga.

Dari beberapa perubahan norma pada perjanjian perkawinan yang telah disebutkan di atas, ada salah satu perubahan norma yang dianggap menarik oleh penulis, yaitu terkait dengan pengesahan perjanjian perkawinan. Di dalam Putusan Mahkamah Konstitusi tersebut memberikan alternatif pengesahan perjanjian perkawinan oleh Notaris.

Notaris adalah pejabat umum yang berwenang untuk membuat akta dalam bentuk otentik terkait semua perbuatan, perjanjian, dan penetapan yang diatur oleh peraturan Undang-Undang atau yang diinginkan oleh pihak yang berkepentingan untuk dinyatakan kedalam sebuah akta otentik, menjamin kepastian dari tanggal pembuatan akta, menyimpan minuta akta, memberikan salinan, grose dan kutipan dari akta, seluruhnya itu sepanjang dalam pembuatan akta itu tidaklah ditugaskan atau dikecualikan pada pejabat atau orang lain yang penetapannya diatur oleh 
peraturan Undang-Undang. Jika melihat ketentuan yang ada pada Pasal 29 ayat (1) dan ayat (2) UU 1/1974 junto Pasal 12 huruf h PP 9/1975, pengesahan perjanjian perkawinan yang dilakukan oleh pegawai pencatatan perkawinan tidak semata-mata hanya mengenai sah atau tidaknya perjanjian perkawinan itu saja, melainkan juga terkait dengan pencatatan perjanjian perkawinan kedalam akta perkawinan.

Perjanjian perkawinan yang disahkan oleh pegawai pencatatan perkawinan merupakan bagian yang tak terpisahkan dari akta perkawinan yang mana perjanjian itu dicatatkan pada akta perkawinan dengan tujuan agar pihak ketiga mengetahui adanya suatu perjanjian perkawinan sehingga perjanjian perkawinan berlaku pula bagi pihak ketiga. $^{8}$

Farida Prihatini berpendapat bahwa perjanjian perkawinan yang dibuat sebelum atau saat perkawinan dilangsungkan dengan dibuat oleh atau dihadapan dan ditandatangani Notaris masih berlaku selama isi perjanjian tersebut tidak melanggar hukum, agama dan kesusilaan, tetapi perjanjian perkawinan tersebut hanya berlaku bagi kedua belah pihak apabila tidak dicatatkan

${ }^{8}$ Martiman Prodjohamidjojo, (2002), Hukum Perkawinan Indonesia, Jakarta: Indonesia Legal Centre Publishing, hlm. 30. di pegawai pencatat perkawinan. ${ }^{9}$ Pencatatan perjanjian perkawinan kedalam akta perkawinan tersebut dinilai penting, karena pasangan suami istri selama masa perkawinannya pastilah melakukan suatu perbuatan hukum dengan pihak ketiga, apabila tidak dilakukan pencatatan, maka perjanjian perkawinan tersebut hanya mengikat bagi para pihak yang membuatnya saja.

Menambahkan kewenangan Notaris dalam hal pengesahan perjanjian perkawinan tak ayal menimbulkan ketidakpastian hukum di dalam masyarakat terutama dikalangan para Notaris dalam melaksanakan tugas dan jabatannya. Hal tersebut dikarenakan pengesahan perjanjian perkawinan tidak hanya mengenai sah atau tidaknya perjanjian perkawinan saja, melainkan juga terkait pencatatan kedalam akta perkawinan dengan tujuan agar pihak ketiga mengetahui adanya suatu perjanjian perkawinan sehingga perjanjian perkawinan berlaku juga bagi pihak ketiga. Notaris tidak memiliki kewenangan atas pencatatan perjanjian perkawinan ke dalam akta perkawinan, karena kewenangan atas pembuatan akta perkawinan merupakan

${ }^{9}$ Farida Prihatini, (2016), Meski Telat, Perjanjian Perkawinan Perlu Didaftarkan (online), http://www.hukumonline.com/berita/baca/lt56a5c5 3a38ebc/meski-telat--perjanjian-perkawinan-perludidaftarkan, (7 Maret 2017). 
kewenangan dari pegawai pencatatan perkawinan dimana perkawinan tersebut dicatatkan.

Rumusan masalah dalam penelitian ini adalah bagaimana peran Notaris terkait pengesahan perjanjian perkawinan pasca Putusan Mahkamah Konstitusi Nomor 69/PUU-XIII/2015?

\section{B. Metode Penelitian}

Adapun metode penelitian yang digunakan oleh penulis dalam menulis tulisan ini adalah dengan menggunakan pendekatan yuridis normatif. Penulis mencoba melakukan kajian pustaka terkait dengan isu yang penulis angkat dalam tulisan ini. Selain itu isu yang penulis angkat juga dikaji dengan melakukan tinjauan terhadap norma-norma hukum yang terdapat dalam peraturan perundangundangan yang terkait dengan industri pelabuhan dan kaitannya dengan perspektif hukum persaingan usaha.

\section{Pembahasan}

Pengesahan Perjanjian Perkawinan Sebelum Putusan Mahkamah Konstitusi Nomor 69/PUU-XIII/2015

Perjanjian perkawinan sebagai persetujuan antara calon suami istri, pada dasarnya adalah sama dengan perjanjian pada umumnya, sebab sama-sama terikat dengan Pasal 1320 KUHPerdata yang mengatur tentang syarat sahnya suatu perjanjian antara lain sepakat, cakap hukum, suatu hal tertentu dan suatu sebab yang halal. Karena perjanjian perkawinan sama dengan perjanjian pada umumnya, maka perjanjian perkawinan mempunyai akibat hukum berlaku seperti UndangUndang bagi para pihak yang membuatnya, sebagaimana tercantum pada Pasal 1338 ayat (1) KUHPerdata yang menyatakan "semua perjanjian yang dibuat secara sah berlaku sebagai UndangUndang bagi mereka yang membuatnya". Para pihak dalam perjanjian itu harus menghormati dan melaksanakan isi dari perjanjian, tidak boleh melakukan perbuatan yang bertentangan dari isi perjanjian.

Sebelum di undangkannya UU 1/1974, mengenai perjanjian perkawinan diatur di dalam Pasal 139 sampai dengan Pasal 179 KUHPerdata. Ada 40 (empat puluh) Pasal dalam KUHPerdata yang mengatur mengenai perjanjian perkawinan. Pasal 139 KUHPerdata menyatakan, "Kedua calon suami istri, dengan mengadakan perjanjian perkawinan dapat menyiapkan penyimpangan dari peraturan Undang-Undang mengenai persatuan harta kekayaan, asalkan perjanjian itu tidak bertentangan atau menyalahi dengan tata susila yang baik atau dengan tata tertib umum, dan diindahkan pula ketentuan- 
ketentuan yang diatur lebih lanjut pada pasal berikutnya".

Berdasarkan ketentuan ini, harta bersama bisa ditiadakan. Namun menurut Pasal 144 KUHPerdata, "ketiadaan persatuan harta kekayaan tidak berarti tidak adanya persatuan untung rugi, kecuali jika secara tegas ditiadakan". Artinya jika di dalam perjanjian perkawinan hanya mengatur mengenai kesepakatan meniadakan persatuan harta kekayaan, maka persatuan untung rugi antara suami istri terjadi secara yuridis tetap ada, kecuali jika persatuan untung rugi tersebut juga ditiadakan dan/atau dituangkan dalam perjanjian perkawinan.

Selanjutnya menurut Pasal 147 KUHPerdata menyatakan "atas ancaman kebatalannya suatu perjanjian perkawinan harus dibuat dengan akta Notaris sebelum perkawinan dilangsungkan dan berlaku setelah perkawinan dilangsungkan. Disini perjanjian perkawinan diwajibkan dibuat dalam bentuk akta Notaris, tetapi undangundang tidak mewajibkan Notaris melakukan pembukuan atau registrasi atas perjanjian perkawinan yang telah dibuatnya.

Kemudian Pasal 148 KUHPerdata menyatakan "perubahan terhadap perjanjian perkawinan hanya bisa dilakukan sebelum perkawinan dilangsungkan serta perubahanya dilakukan dengan persetujuan para pihak yang membuatnya”. Pasal 149 KUHPerdata menyatakan "setelah perkawinan berlangsung suatu perjanjian perkawinan tidak dapat diubah". Berdasarkan Pasal 148 dan Pasal 149 KUHPerdata tersebut, perubahan perjanjian perkawinan hanya dapat diubah sebelum perkawinan dilangsungkan, jadi apabila perkawinan telah dilangsungkan maka perjanjian perkawinan tidak dapat diubah.

Lebih jauh lagi, Pasal 152 KUHPerdata mengatur mengenai pencatatan atau pembukuan perjanjian perkawinan yang menyatakan "perjanjian perkawinan tidak berlaku terhadap pihak ketiga apabila tidak dicatatkan atau dibukukan ke dalam register umum pada Kepaniteraan Pengadilan Negeri di daerah hukum perkawinan dilangsungkan atau jika perkawinan dilangsungkan di luar negeri, maka pencatatan atau pembukuan perjanjian perkawinan dilakukan di Kepaniteraan Pengadilan Negeri tempat dicatatnya perkawinan".

Hakikat dari pembukuan atau registrasi atas perjanjian perkawinan pada Pasal 152 KUHPerdata adalah bertujuan untuk mengikat pihak ketiga kedalam perjanjian perkawinan. Pembukuan atau registrasi perjanjian perkawinan adalah bentuk pemenuhan asas publikasi, 
sehingga pihak ketiga mengetahui adanya perjanjian perkawinan dan memberikan kepastian hukum terhadap pihak ketiga. ${ }^{10}$

Setelah diundangkannya UU 1/1974 dan berlaku bagi seluruh bangsa Indonesia sejak tanggal 1 Oktober 1975, menurut Pasal 66 UU 1/1974 ketentuan-ketentuan mengenai perkawinan di dalam KUHPerdata serta peraturan-peraturan lain yang mengatur tentang perkawinan dinyatakan tidak berlaku lagi, akan tetapi hal tersebut tidak semata-mata menghapuskan ketentuan-ketentuan dan peraturan-peraturan lain tersebut sepanjang hal itu belum diatur di dalam UU 1/1974.

Menurut Prof. H. R. Sardjono jika melihat rumusan pada Pasal 66 UU 1/1974, maka UU 1/1974 tidaklah mencabut secara menyeluruh ketentuanketentuan dan peraturan-peraturan lain yang mengatur perkawinan, melainkan hanya menghapus kekuatan hukum ketentuan-ketentuan dan peraturanperaturan lain terkait perkawinan yang telah diatur di dalam UU 1/1974. Apabila belum diatur di dalam UU 1/1974, maka masih berlaku ketentuan yang lama sepanjang ketentuan tersebut tidak bertentangan dengan UU 1/1974. ${ }^{11}$

\footnotetext{
${ }^{10}$ Herlien Budiono, (2010), Kumpulan Tulisan Hukum Perdata di Bidang Kenotariatan Buku Kedua, Bandung: Citra Aditya Bakti, hlm. 7.

${ }^{11}$ Rusdi Malik, (2009), Memahami UndangUndang Perkawinan, Jakarta: Universitas Trisakti, hlm. 25.
}

Pada UU 1/1974, mengenai perjanjian perkawinan hanya diatur di dalam 1 (satu) pasal yang terdiri dari 4 (empat) ayat yaitu Pasal 29. Adapun ketentuan dari pasal tersebut adalah sebagi berikut:

(1) Pada waktu atau sebelum perkawinan dilangsungkan, kedua pihak atas persetujuan bersama dapat mengadakan perjanjian tertulis yang disahkan oleh Pegawai Pencatat Perkawinan, setelah mana isinya berlaku juga terhadap pihak ketiga sepanjang pihak ketiga tersangkut.

(2) Perjanjian tersebut tidak dapat disahkan bilamana melanggar batas hukum, agama dan kesusilaan.

(3) Perjanjian tersebut berlangsung semenjak perkawinan dilangsungkan.

(4) Selama perkawinan berlangsung perjanjian tersebut tidak dapat diubah, kecuali bilamana dari kedua belah pihak ada persetujuan untuk mengubah dan perubahan tidak merugikan pihak ketiga.

Jika dilihat, ketentuan-ketentuan yang ada di dalam KUHPerdata jauh lebih lengkap mengatur mengenai perjanjian perkawinan dari pada yang ada pada Pasal 29 UU 1/1974. Bahkan di dalam PP 9/1975 sebagai peraturan pelaksana dari UU 1/1974, tidak mengatur lebih lanjut 
mengenai perjanjian perkawinan. Dari ketentuan-ketentuan yang mengatur perjanjian perkawinan di dalam KUHPerdata dan UU 1/1974 tersebut, apabila diamati lebih lanjut maka akan didapatkan beberapa perbedaan. Adapun perbedaannya adalah sebagai berikut:

a. KUHPerdata mewajibkan perjanjian perkawinan dibuat dengan akta Notaris, sedangkan menurut UU 1/1974 tidak ada ketentuan yang mengharuskan perjanjian perkawinan dibuat dengan akta Notaris. Namun para pihak yang bekepentingan tetap dapat membuat perjanjian perkawinan kedalam akta Notaris apabila para pihak tersebut menghendakinya.

b. Agar perjanjian perkawinan mengikat pihak ketiga, menurut KUHPerdata perjanjian perkawinan harus dibukukan pada Kepaniteraan Pengadilan Negeri setempat, sedangkan menurut UU 1/1974 perjanjian perkawinan harus disahkan oleh pegawai pencatat perkawinan dimana perkawinan itu dicatatkan.

c. Perjanjian perkawinan menurut KUHPerdata hanya bisa dibuat sebelum perkawinan dilangsungkan, sedangkan menurut UU $1 / 1974$ perjanjian perkawinan dapat dibuat sebelum atau pada saat perkawinan dilangsungkan. d. Perjanjian perkawinan di dalam KUHPerdata tidak dapat diubah setelah perkawinan dilangsungkan, sedangkan menurut UU 1/1974 perjanjian perkawinan dapat diubah setelah dilangsungkanya perkawinan asalkan ada kesepakatan antara kedua belah pihak serta perubahannya tidak merugikan bagi pihak ketiga.

Dari perbedaan pengaturan perjanjian perkawinan yang ada di dalam KUHPerdata dengan UU 1/1974 terdapat perbedaan yang signifikan mengenai syarat agar suatu perjanjian perkawinan mengikat juga bagi pihak ketiga. Pada KUHPerdata untuk mengikat pihak ketiga perjanjian perkawinan perlu dicatatkan atau dibukukan ke dalam register umum pada Kepaniteraan Pengadilan Negeri di daerah hukum perkawinan dilangsungkan atau jika perkawinan dilangsungkan di luar negeri, maka pencatatan atau pembukuan perjanjian perkawinan dilakukan di Kepaniteraan Pengadilan Negeri tempat dicatatnya perkawinan.

Berbeda dengan UU 1/1974 yang menyatakan untuk mengikat pihak ketiga, maka perlu dilakukan pengesahan perjanjian perkawinan oleh Pegawai Pencatatan Perkawinan. Jika ditinjau berdasarkan teori kewenangan menurut Philipus M. Hadjon sebagai mana telah 
disampaikan pada kerangka teoritik, maka didapati bahwa kewenangan dalam mengesahkan perjanjian perkawinan adalah tergolong kewenangan yang bersifat atribusi, yaitu kewenangan tersebut langsung diberikan dan bersumber dari undang-undang. Kewenangan tersebut langsung diberikan kepada pegawai pencatatan perkawinan oleh UU 1/1974.

Frasa “... perjanjian tertulis yang disahkan oleh pegawai pencatat perkawinan setelah mana isinya berlaku juga terhadap pihak ketiga..." pada Pasal 29 Ayat (1) UU 1/1974 menjadi landasan perlunya dilakukan pengesahan perjanjian perkawinan oleh pegawai pencatatan perkawinan, sehingga perjanjian perkawinan tersebut berlaku juga bagi pihak ketiga. Pengertian "pengesahan" atau perbuatan mengesahkan; pengakuan berdasarkan hukum; peresmian; pembenaran $^{12}$ dalam ruang lingkup hukum adalah tindakan hukum oleh pihak yang berwenang untuk mengubah status "tidak sah" menjadi "sah" sebagaimana halnya mengubah dari bukan badan hukum menjadi bahan hukum.

Seperti halnya dalam menjalankan kewenangannya, Kementerian Hukum dan Hak Asasi Manusia Republik Indonesia (Kemenkumham) sebelum memberikan

\footnotetext{
${ }^{12}$ Departemen Pendidikan Nasional, (2005), Kamus Besar Bahasa Indonesia, Edisi Ketiga, Jakarta: Balai Pustaka, hlm. 977.
}

pengesahan suatu badan hukum pada perseroan terbatas, perhimpunan atau yayasan terlebih dahulu mempertimbangkan apakah anggaran dasar dari perseroan terbatas, perhimpunan atau yayasan tersebut tidak bertentangan dengan undang-undang, kesusilaan dan ketertiban umum serta telah memenuhi syarat-syarat lainnya. ${ }^{13}$

Hal ini berbeda dengan pengesahan yang dilakukan oleh pegawai pencatatan perkawinan selama ini yang tidak pernah menolak pengesahan perjanjian perkawinan, pejabat yang bersangkutan malahan tidak meneliti lebih jauh apakah isi dari perjanjian perkawinan tersebut mengandung hal-hal yang melanggar batas-batas hukum, agama dan kesusilaan walaupun bunyi Pasal 29 Ayat (2) UU 1/1974 melarang pengesahan perjanjian perkawinan apabila melanggar batas-batas tersebut. $^{14}$

Pengesahan perjanjian perkawinan di dalam praktek hanya mungkin dilakukan pada saat pencatatan perkawinan dilakukan, sehingga bagi mereka yang lupa atau tidak mencatatakan pada saat perkawinan dicatatkan tidak dapat mengesahkan perjanjian perkawinannya. Penafsiran tersebut mungkin sekali disebabkan oleh bunyi ketetentuan Pasal

\footnotetext{
${ }^{13}$ Herlien Budiono, Op.Cit. hlm. 14.

${ }^{14}$ Herlien Budiono, Loc. Cit.
} 
12 huruf h PP 9/1975 yang menyebutkan bahwa akta perkawinan memuat diantaranya "perjanjian perkawinan apabila ada". Tanpa adanya keterangan lebih lanjut mengenai maksud pembuat Undang-Undang mengenai “disahkan”, maka hanya semata-mata karena di dalam PP 9/1975 tersebut mengatur agar mencantumkan di dalam akta perkawinan "perjanjian perkawinan apabila ada" menyebabkan pegawai pencatatan perkawinan juga akan menolak pengesahan selain pada waktu perkawinan dicatatkan. $^{15}$

Secara harafiah pengertian hukum dari kata "dibukukan" dalam arti (overschrijving), seperti yang dimaksud dalam pasal 152 KUHPerdata sebagai syarat bagi berlakunya perjanjian perkawinan terhadap pihak ketiga, adalah berbeda maknanya dengan pengertian hukum dari kata "pengesahan" yang berarti (bewilligen) seperti yang dimuat dalam Pasal 36 KUH Dagang (Wetboek van Koophandel) ${ }^{16}$, akan tetapi pada kenyataannya saat ini, pengesahan perjanjian perkawinan oleh pegawai pencatatan perkawinan tidak lebih dari pembukuan (overschrijving) perjanjian

\footnotetext{
${ }^{15}$ Ibid. hlm. 15.

${ }^{16}$ Sylvia Widjaja, (2015), Aneka Permasalahan Mengenai Perjanjian Kawin Pengesahan Atau Pencatatan, Dialogia Iuridica, Volume 7, Nomor 1, Fakultas Hukum Universitas Kristen Maranatha, Bandung, 2015, hlm 85.
}

perkawinan dalam suatu register umum (openbaar register) yang harus diselenggarakan untuk itu di Kepaniteraan Pengadilan Negeri di dalam daerah hukumnya perkawinan telah dilangsungkan sebagaimanan halnya pada perjanjian perkawinan menurut Pasal 152 KUHPerdata. ${ }^{17}$ Akibat tidak disahkannya perjanjian perkawinan terhadap pihak ketiga adalah sama dengan tidak dibukukannya perjanjian perkawinan yang menurut pendapat Henry Lee A Weng dalam disertasinya sebagaimana diuraikan oleh Herlien Budiono adalah dalam hal: ${ }^{18}$

“(..) Apabila suami atau istri dapat
membuktikan bahwa ketentuan-
ketentuan yang tidak diumumkan
(yang dimaksud adalah disahkan',
dari penulis) itu telah diketahui
pihak ketiga sebelum atau pada saat
mereka mengadakan hubungan
hukum dengan suami dan atau istri,
ketentuan-ketentuan tersebut
berlaku terhadap pihak ketiga yang
mengetahui. Pihak ketiga dapat
mengetahui adanya perjanjian
perkawinan itu telah diperlihatkan
oleh suami atau istri kepada pihak
ketiga tersebut."
Selain itu apabila diperhatikan frasa “...setelah mana isinya berlaku juga terhadap pihak ketiga, sepanjang pihak ketiga tersangkut" pada pasal 29 ayat (1) UU 1/1974, menunjukan bahwa pengesahan tersebut hanya disyaratkan bagi berlakunya perjanjian perkawinan

\footnotetext{
${ }^{17}$ Herlien Budiono, Op. Cit. hlm. 15.

${ }^{18}$ Herlien Budiono, Loc. Cit.
} 
terhadap pihak ketiga yang tersangkut dan bukan disyaratkan bagi berlakunya perjanjian perkawinan terhadap suami istri yang membuatnya.

Adapun dengan belum disahkan atau dicatatkannya akta perjanjian perkawinan tersebut oleh pegawai pencatatan perkawinan hingga saat perkawinan dilangsungkan, tidak mengurangi keabsahan dan berlakunya perjanjian perkawinan tersebut terhadap suami istri yang bersangkutan oleh karena pengesahan atau pencatatan perjanjian perkawinan oleh pegawai pencatatan perkawinan menurut Pasal 29 ayat (1) UU 1/1974 hanya disyaratkan bagi berlakunya perjanjian perkawinan tersebut terhadap pihak ketiga terkait.

Dengan demikian, terhadap hakikat pengesahan perjanjian perkawinan dapat dikatakan tujuan dari pengesahan perjanjian perkawinan meskipun menggunakan istilah "pengengesahan" adalah sama dengan hakikat pembukuan pada Pasal 152 KUHPerdata, yang mana saat ini berdasarkan Pasal 2 dan Pasal 12 huruf h PP 9/1975 tidak lagi dilakukan di Kepaniteraan Pengadilan Negeri melainkan di Kantor Urusan Agama (KUA) untuk yang beragama Islam dan Kantor Catatan Sipil untuk yang beragama salain Islam yang kemudian dicatatkan ke dalam akta perkawinan.
Berdasarkan uraian-uraian diatas, maka dapat disimpulkan bahwa pengesahan perjanjian perkawinan sebagai perjanjian tertulis (yang berisi janji-janji perkawinan) dengan pengesahan perjanjian perkawinan dengan tujuan untuk mengikat pihak ketiga merupakan dua hal yang berbeda. Perjanjian perkawinan sebagai perjanjian tertulis dikatakan sah dan mengikat bagi para pihak yang membuatnya apabila ditandatangani oleh para pihak dan telah memenuhi syarat sahnya suatu perjanjian (Pasal 1320 KUHPerdata).

Sedangkan, pengesahan perjanjian perkawinan dengan tujuan untuk mengikat pihak ketiga dikatakan sah apabila telah disahkan oleh pegawai pencatatan perkawinan (dalam artian dibukukan seperti Pasal 152 KUHPerdata) yang mana pengesahan perjanjian perkawinan tersebut tidak dapat diberikan apabila perjanjian perkawinan itu melanggar batas hukum, agama dan kesusilaan. Dengan kata lain sahnya suatu perjanjian perkawinan bagi para pihak yang membuatnya bukan berarti sah terhadap pihak ketiga.

Pengesahan Perjanjian Perkawinan Sesudah Putusan Mahkamah Konstitusi Nomor 69/PUU-XIII/2015

Pada tanggal 27 Oktober 2016, Mahkamah Konstitusi mengabulkan 
sebagian permohonan perkara Nomor 69/PUU-XIII/2015 yang diajukan oleh saudari Ike Farida selaku pemohon. Isi pokok permohonannya adalah terkait dengan uji materi beberapa ketentuan dalam Undang-undang Nomor 5 Tahun 1960 tentang Peraturan Dasar PokokPokok Agraria dan Undang-Undang Nomor 1 Tahun 1974 Tentang Perkawinan (UU 1/1974). Pemohon mengajukan uji materi atas Pasal 21 ayat (1) dan ayat (3), serta Pasal 36 ayat (1) UUPA dan Pasal 29 ayat (1), ayat (3), ayat (4) dan Pasal 35 ayat (1) UU 1/1974.

Dasar permohonan uji materi tersebut secara sederhana berawal dari keadaan dimana pemohon merasa hak konstitusionalnya telah dilanggar karena tidak dapat melakukan proses pensertifikatan Hak Milik atas Satuan Rumah Susun (HMSRS) yang dibeli oleh pemohon dari pengembang. Pihak pengembang beralasan tidak dapat melakukan proses pensertifikatan karena pemohon terikat perkawinan dengan Warga Negara Asing (WNA) dan pada saat perkawinan dilangsungkan tidak terdapat perjanjian perkawinan. Di dalam Putusan tersebut, Mahkamah Konstitusi menambahkan norma baru terkait pengesahan perjanjian perkawinan.
Adapun penambahan norma itu dapat dilihat didalam amar putusannya sebagai berikut:

a. Pasal 29 ayat (1) Undang-Undang Nomor 1 Tahun 1974 tentang Perkawinan (Lembaran Negara Republik Indonesia Tahun 1974 Nomor 1, Tambahan Lembaran Negara Republik Indonesia Nomor 3019) bertentangan dengan Undang-Undang Dasar Negara Republik Indonesia Tahun 1945 sepanjang tidak dimaknai "Pada waktu, sebelum dilangsungkan atau selama dalam ikatan perkawinan kedua belah pihak atas persetujuan bersama dapat mengajukan perjanjian tertulis yang disahkan oleh pegawai pencatat perkawinan atau notaris, setelah mana isinya berlaku juga terhadap pihak ketiga sepanjang pihak ketiga tersangkut";

b. Pasal 29 ayat (1) Undang-Undang Nomor 1 Tahun 1974 tentang Perkawinan (Lembaran Negara Republik Indonesia Tahun 1974 Nomor 1, Tambahan Lembaran Negara Republik Indonesia Nomor 3019) tidak mempunyai kekuataan hukum mengikat sepanjang tidak dimaknai "Pada waktu, sebelum dilangsungkan atau selama dalam ikatan perkawinan kedua belah pihak atas persetujuan bersama dapat mengajukan perjanjian tertulis yang disahkan oleh pegawai pencatat perkawinan atau notaris, setelah mana isinya berlaku juga terhadap pihak ketiga sepanjang pihak ketiga tersangkut";

Jika memperhatikan amar putusan di atas, Mahkamah Konstitusi menambahkan frasa "atau Notaris" setelah frasa “...disahkan oleh pegawai pencatatan perkawinan". Hal itu merupakan hal baru terkait dengan pengesahan perjanjian 
perkawinan, meskipun sudah lama dikenal dalam prakteknya saat ini bahwa perjanjian perkawinan selalu dibuat ke dalam bentuk akta Notaris sebagaimana diatur di dalam Pasal 147 KUHPerdata, tetapi berdasarkan Pasal 29 ayat (1) UU 1/1974, keharusan membuat perjanjian perkawinan dengan akta Notaris tidak lagi mengikat. Selain itu Mahkamah Konstitusi juga mengubah frasa "mengadakan perjanjian tertulis" yang ada pada Pasal 29 ayat (1) UU 1/1974 menjadi "mengajukan perjanjian tertulis".

Berdasarkan penambahan dan perubahan frasa yang di lakukan oleh Mahkamah Konstitusi terhadap rumusan Pasal 29 ayat (1) UU 1/1974, jika dikaitkan dengan frasa “...setelah mana isinya berlaku juga terhadap pihak ketiga sepanjang pihak ketiga tersangkut" yang tetap dipertahankan oleh Mahkamah Konstitusi, maka didapati bahwa Mahkamah Konstitusi memberikan kewenangan baru kepada Notaris untuk mengesahkan perjanjian perkawinan dengan tujuan mengikat pihak ketiga. Disini dapat dikatakan bahwa peran Notaris adalah untuk mengesahkan perjanjian perkawinan yang sudah ada dan bukan untuk membuat perjanjian perjanjian perkawinan.

Hal tersebut dikarenakan adanya perubahan frasa "mengadakan perjanjian tertulis" menjadi "mengajukan perjanjian tertulis". Menurut KBBI, pengertian "mengadakan" dengan "mengajukan" adalah berbeda. Mengadakan adalah menjadikan, menciptakan atau menyebabkan sesuatu yang tidak ada menjadi ada, sedangkan mengajukan adalah mengemukakan, membawa kedepan atau menampilkan sesuatu yang sudah ada. ${ }^{19}$

Jadi ada 2 (dua) peran Notaris pasca Putusan Mahkamah Konstitusi Nomor 69/PUU-XIII/2015:

Pertama, Notaris berperan sebagai pihak yang berwenang dalam pengesahan perjanjian perkawinan sebagai perjanjian tertulis dalam artian membuat perjanjian perkawinan ke dalam akta Notaris bilamana para pihak menghendakinya sebagaimana kewenangan Notaris pada Pasal 15 ayat (1) UU 2/2014.

Kedua, Notaris berperan sebagai pihak yang berwenang untuk mengesahkan perjanjian perkawinan yang sudah ada dengan tujuan agar perjanjian perkawinan tersebut mengikat pula bagi pihak ketiga.

Mahkamah Konstitusi memberikan kewenangan baru yang sebelumnya tidak diatur di dalam Undang-Undang Jabatan Notaris (UU 2/2014). Kewenangan tersebut adalah untuk mengesahkan

\footnotetext{
${ }^{19}$ Ebta Setiawan, (2012), Kamus Besar Bahasa Indonesia (online), https://kbbi.web.id, (20 September 2017).
}

Volume 2 No.1 April 2018

ISSN Cetak: 2579-9983, E-ISSN: 2579-6380

Halaman. 87-104 
perjanjian perkawinan yang diajukan oleh kedua belah pihak (suami istri). Perjanjian perkawinan yang dibuat ke dalam akta Notaris tidak serta merta sah mengikat pihak ketiga, melainkan hanya berlaku sah terhadap para pihak yang membuatnya karena untuk mengikat pihak ketiga dibutuhkan tindakan yang berkaitan dengan asas publikasi. Asas publikasi adalah kewajiban membuka informasi agar publik (masyarakat umum) mengetahui informasi tersebut. Asas publikasi tersebut terlihat bertentangan dengan asas kerahasiaan yang digunakan Notaris dalam menjalankan tugas dan jabatannya sebagaimana diatur di dalam Pasal 16 ayat (1) dan Pasal 54 ayat (1) UU 2/2014.

Di dalam Pasal 16 ayat (1) huruf $\mathrm{f}$ UU 2/2014 menyatakan bahwa Notaris wajib "merahasiakan segala sesuatu mengenai akta yang dibuatnya dan segala keterangan yang diperoleh guna pembuatan akta sesuai dengan sumpah/janji jabatan, kecuali undangundang menentukan lain". Pasal 54 ayat (1) UU 2/2014 menyatakan "Notaris hanya dapat memberikan, memperlihatkan atau memberitahukan isi akta, grosse akta, salinan akta atau kutipan akta kepada orang yang berkepentingan langsung kepada akta, ahli waris atau orang yang memperoleh hak, kecuali ditentukan lain oleh peraturan perundang-undangan”.
Berdasarkan hal itu, apabila dalam pengesahan perjanjian perkawinan kemudian Notaris mencatatkannya ke dalam repertorium seperti pencatatan akta Notaris lainnya, maka hal itu tidak dapat dikatakan sebagai asas publikasi dimana kemudian perjanjian perkawinan tersebut mengikat pihak ketiga, karena repertorium tidak dapat diakses oleh masyarakat umum.

Repertorium hanya bisa diakses oleh pihak-pihak yang berkepentingan langsung pada akta, ahliwaris atau orang yang memperoleh hak. Berbeda dengan pencatatan kedalam akta perkawinan yang dilakukan pegawai pencatatan perkawinan yang mana hal tersebut dapat diakses oleh masyarakat umum.

Selain itu perjanjian perkawinan wajib dicatatkan kedalam akta perkawinan apabila ada sebagaimana diatur di dalam Pasal 12 huruf h PP 9/1975 dan Notaris tidaklah memiliki kewenangan atas pencatatan perjanjian perkawinan ke dalam akta perkawinan, karena kewenangan atas pencatatan perjanjian perkawinan kedalam akta perkawinan adalah kewenangan dari Kantor Urusan Agama untuk yang melangsungkan perkawinan menurut agama Islam dan Kantor Pencatatan Sipil untuk yang melangsungkan perkawinan menurut agama selain Islam (Pasal 2 PP 9/1975). 
Beranjak dari uraian-uraian di atas, maka saat ini Notaris tidak serta merta dapat mengesahkan perjanjian perkawinan sebagaimana yang di maksud di dalam Putusan Mahkamah Konstitusi Nomor 69/PUU-XIII/2015. Untuk itu perlu mekanisme baru yang dapat diatur dalam peraturan pelaksanaan. Sebagai contoh (analogi) adalah pendaftaran wasiat, pendaftaran fidusia, perkumpulan, yayasan atau pengesahan perseroan terbatas yang dipusatkan di Direktoran Jendral Administrasi Hukum Umum Kementerian Hukum Dan Hak Asasi Manusia Republik Indonesia, sehingga pengesahan perjanjian perkawinan yang dilakukan oleh Notaris dapat diakses untuk umum dan dapat memberikan kepastian hukum bagi para pihak yang terlibat di dalam perjanjian perkawinan (termasuk pihak ketiga) dan juga Notaris yang mengesahkan.

Sebelum adanya sistem pencatatan yang terintegrasi atas pengesahan perjanjian perkawinan oleh Notaris, maka sepatutnya pengesahan perjanjian perkawinan dengan tujuan untuk mengikat pihak ketiga tetap dilakukan oleh pegawai pencatatan perkawinan.

Dengan kata lain saat ini Notaris tetap menjalankan peran sebelumnya yaitu sebagai pihak yang melakukan pengesahan perjanjian perkawinan sebagai perjanjian tertulis (membuat perjanjian perkawinan kedalam akta Notaris) jika dikehendaki oleh para pihak.

\section{Penutup}

Ada 2 (dua) peran Notaris terkait pengesahan perjanjian perkawinan pasca Putusan Mahkamah Konstitusi Nomor 69/PUU-XIII/2015 yaitu:

1. Notaris berperan sebagai pihak yang mengesahkan perjanjian perkawinan sebagai perjanjian tertulis yang dalam artian membuat perjanjian perkawinan kedalam akta Notaris apabila pembuatan perjanjian perkawinan kedalam akta Notaris itu dikehendaki oleh para pihak.

2. Notaris berperan sebagai pihak yang mengesahkan perjanjian perkawinan yang sudah ada atau telah dibuat oleh para pihak (suami istri) dengan tujuan agar perjanjian perkawinan tersebut mengikat juga bagi pihak ketiga. Akan tetapi saat ini Notaris tidak serta merta dapat menjalankan pengesahan perjanjian perkawinan dengan tujuan agar perjanjian perkawinan mengikat juga bagi pihak ketiga karena masih dibutuhkan peraturan pelaksana yang terintergrasi untuk memenuhi asas publikasi, sehingga pihak ketiga mengetehaui adanya perjanjian perkawinan. Untuk itu saat ini sepatutnya pengesahan perjanjian

Volume 2 No.1 April 2018

ISSN Cetak: 2579-9983, E-ISSN: 2579-6380

Halaman. 87-104 
perkawinan dengan tujuan mengikat pihak ketiga tetap dilakukan oleh pegawai pencatatan perkawinan.

\section{E. Daftar Pustaka}

Buku

Amirudin dan H. Zainal Asikin, (2008), Pengantar Metode Penelitian Hukum, Edisi ke-1, Cetakan IV, Jakarta: PT. Raja Grafindo Persada.

Departemen Pendidikan Nasional, (2005),

Kamus Besar Bahasa Indonesia,

Edisi Ketiga, Jakarta: Balai Pustaka.

Herlien Budiono, (2010), Kumpulan

Tulisan Hukum Perdata di Bidang

Kenotariatan Buku Kedua, Bandung:

Citra Aditya Bakti.

Khomariah, (2004), Hukum Perdata, Malang: UMM Press.

Martiman Prodjohamidjojo, (2002),

Hukum Perkawinan Indonesia,

Jakarta: Indonesia Legal Centre Publishing.

Rusdi Malik, (2009), Memahami Undang-

Undang Perkawinan, Jakarta: Universitas Trisakti.

Subekti, (2004), Ringkasan Tentang Hukum Keluarga dan Hukum Waris, Cet. 4, Jakarta: PT. Intermasa.

Wahyono Darmabrata, (2008), Tinjauan Undang-Undang No. 1 Tahun 1974 Tentang Perkawinan beserta
Undang-Undang dan Peraturan

Pelaksanaannya, Jakarta: Rizkita

Wahyono Darmabrata, (2009), Hukum

Perkawinan Perdata (Syarat Sahnya Perkawinan, Hak dan Kewajiban Suami Istri, Harta Benda Perkawinan), Jakarta: Rizkita.

Jurnal

Sylvia Widjaja, (2015), Aneka Permasalahan Mengenai Perjanjian Kawin Pengesahan Atau Pencatatan, Dialogia Iuridica, Volume 7, Nomor 1, Fakultas Hukum Universitas Kristen Maranatha, Bandung, 2015.

Makalah Seminar Hukum

Moch. Isnaaeni, Problematika Perjanjian Kawin Pasca Putusan Mahkamah Konstitusi No. 69/PUU-XIII/2015, Makalah disajikan dalam Seminar Nasional, Himpunan Mahasiswa Kenotariatan Universitas Airlangga, Surabaya, 5 Desember 2016.

Worl Wide Web

Arko Kanadianto, (2016), Pembuatan Perjanjian Pisah Harta Pasca Putusan Mahkamah Konstitusi No. 69/PUUXIII/2015, Tersedia pada: http://arkokanadianto.com/, [Akses, 10 Maret 2017]. 
Farida Prihatini, (2016), Meski Telat,

Perjanjian Perkawinan Perlu

Didaftarkan

Tersediapada:http://www.hukumonli

ne.com/berita/baca/lt56a5c53a38ebc/

meski-telat--perjanjian-perkawinan-

perlu-didaftarkan, [Akses, 7 Maret 2017].

Ebta Setiawan, (2012), Kamus Besar

Bahasa Indonesia, Tersedia pada:

https://kbbi.web.id, [Akses, 20

September 2017]. 